\title{
Roosevelt's Qualifications and Necessity to Run for a Third Term
}

Taylor $\mathbf{D}^{*}$

Department of Political Science, Saint Leo University, USA

*Corresponding author: Taylor D, Department of Political Science, Saint Leo University, USA, Tel: 1-941-2750448; E-mail: adtwildcat@gmail.com

Received date: Sept 01, 2018; Accepted date: Sept 06, 2018; Published date: Sept 12, 2018

Copyright: (C) 2018 Taylor D. This is an open-access article distributed under the terms of the Creative Commons Attribution License, which permits unrestricted use, distribution, and reproduction in any medium, provided the original author and source are credited.

\begin{abstract}
In the post-Great Depression era of American politics, Franklin Delano Roosevelt was the cornerstone for rebuilding a sound foundation for a new America. Through his first two terms as President, the country had newfound faith in the government, and seeds of hope were beginning to grow out of the hardships of the Great Depression. But with the looming 1940 election cycle being fought between inadequate candidates, and war in Europe becoming more of a reality, Roosevelt was faced with the opportunity of running for an unprecedented third term. He personally had no desire to do so, but the country was begging for his continued leadership. The public supported his programs and aiding our Allies in Europe. The parallels between FDR and presidents of the past are uncanny. Through meetings and personal interactions, no Republican or Democrat could withstand the rigors of President or continue with a vision for a better America. It is because of these views Roosevelt had, he quickly realized that he was the most qualified person to govern the nation and run for a third presidential term.
\end{abstract}

Keywords: Arts; Politics; Social science

\section{Introduction}

Throughout history, world leaders have been asked to go above and beyond what they are prescribed to do in times of crisis. In 1940, Roosevelt had no desire to run for a third term. He had begun transferring papers to his library and wished to retire. But after seeing the field of candidates, he could no longer stay out of reelection discussion. The public sought his leadership and experience in continued rebuilding in a post-depression America, and at the thought of Great Britain being pushed to the brink of collapse. By also comparing how past presidents dealt with the task and duties of the office, Roosevelt's decision to run for an unthinkable third presidential term was necessary. Having been a tradition since the inception of the office by George Washington, Roosevelt ultimately decided to throw his hat into the ring and break one of the most enduring traditions in American politics. As both a shock and a welcoming surprise, Roosevelt would go on to change the course of history more than he could have ever thought. With this, FDR saw himself and his political ideology as the only person that was qualified enough to take on the global threat of a collapsing Europe, conserving his legacy in the New Deal programs, and leading America in a time of emergency.

\section{Personal Feelings towards Re-election}

Roosevelt was a very introverted person when it came to how he felt about things happening in his life. He was never very open about how he dealt with his illness, was nearly emotionless when a serious issue arose, and no confidant to confide in when it came to decisions on policies, or the elephant in the room, his third term reelection bid (Moe, Roosevelt's Second Act, p. 95-98, 180). This conservatism of himself created a wall around him that made what he said hard to distinguish between his sarcasm and commendation on subjects being discussed. It was known within Roosevelt's inner circle however that his openness and desire to retire from politics and live out his life in Hyde Park, New York was prevalent. He knew that he was growing too old too quickly for the office of president, and that the strain on him was immense. One of his staffers was said to have described Roosevelt as, "he had aged 20 years just in his second term alone." That shows just how demanding the job truly was. To further support his wish to return to Hyde Park, in the summer of 1939, FDR had begun moving some of his possessions back to his estate in the case that he would not run for reelection. In the process of moving his belongings, this was establishing his presidential library which at the time meant game over. In Richard Moe's book, he skillfully writes about how FDR went about moving his belongings to Hyde Park in preparation for retirement [1]:

As we have seen, the president had taken a series of concrete steps to plan for what he anticipated would be a fulfilling and financially secure retirement. He had designed and broken ground for his presidential library, which would be ready for use by the next year. White house cook and housekeeper Henrietta Nesbitt said that during early 1940, "we were clearing out storerooms... in fact, the Roosevelts were closing up." His cousin Daisy Suckley, in charge of the transfer of papers and memorabilia to the new library, reported that FDR brought "gobs of stuff" with him every time he returned to Hyde Park during this period [1].

When things outside of his control began to get out of hand in Europe and domestically in politics, he stopped his transfer of documents and assumed his presence in politics again. After talks with current party members, and his cabinet, FDR felt that nobody within the Democratic party was worthy to take his seat in the white house. In terms of ideology, Roosevelt saw himself as the perfect liberal. Just enough progressive appeal, but not too much to run off Republican support. Richard Moe goes on to state in his book that it was evident enough that when Jim Farley had summoned up enough gumption to ask FDR his opinions on whether he had a chance at winning the nomination for Democrats. Roosevelt chuckled at the notion of Farley being president and said, "go ahead. Give it a shot. Why not" (Moe, p. 105). He knew that after the meeting with Farley, there was no realistic person to replace him in office. A sense of duty to the American people to continue rebuilding was found much like how Washington saw his tenure as necessary to lead in a time of emergency. FDR realized that 
he had to go against his emotions and dreams of retirement to make sure that there would be a qualified person leading the country.

\section{Public Opinion of Roosevelt and a Possible Third Term}

The American public in the 1930's was one that was full of pessimism and despair. They had just had the time of their lives during the roaring twenties, but soon faced the harsh world of vast economic instability with the onset of the Great Depression. Roosevelt however came along and ushered in a new wave a social program funded by the government that promised great things to the public. With the progress being made in his New Deal initiatives, people loved how FDR governed the country. He was seen as a beacon of hope not by just the general public, but within congress and the outside world as well. If problems arose in these programs, Roosevelt promised to try something new if they didn't work [2]. This gave him an even better relationship with the people because it showed them that he wasn't going to roll over if something went wrong like Hoover. People believed in him, and what he had done in his previous eight years.

Helmut Norpoth's journal To Change or Not to Change Horses: The World War II Elections, uses public opinion polls from the time immediately after Roosevelt's death in 1945 to answer many questions about Roosevelt's tenure as president [3]. These polls ask two important questions: Voter Intention and Hypothetical Vote in the Absence of War (1940 and 1944), and Attitudes towards War among Potential FDR Defectors (1940 and 1944). In the case that there had not been a war in 1940, Roosevelt was favored to lose the election to Wendell Willkie, 50.9-42.8\% (Table 1) [3].

\begin{tabular}{|l|l|l|l|l|l|}
\hline \multirow{2}{*}{$\begin{array}{l}\text { If there were no war, would vote } \\
\text { for }\end{array}$} & Intended vote & Willkie & Undecided & Total & Percent \\
\cline { 2 - 6 } & FDR & 29 & 26 & 1,267 & $42.8 \%$ \\
\hline FDR & 1,212 & 1,247 & 69 & 1,504 & $50.09 \%$ \\
\hline Willkie & 188 & 20 & 94 & 186 & $6.3 \%$ \\
\hline Undecided & 72 & 1,296 & 189 & 2,957 & $100 \%$ \\
\hline Total & 1,472 & $43.8 \%$ & $6.4 \%$ & $100 \%$ & - \\
\hline Percent & $49.8 \%$ & & & \\
\hline Source: Gallup poll, October 7-12, 1940 (\#1940-0214, Forms K and T) & & & \\
\hline
\end{tabular}

Table 1: Vote Intention and Hypothetical Vote in the absence of war, 1940 election.

This played into the thought process for FDR leading up to primary season in 1939 and 1940. He had seen firsthand how well Willkie was received, and had told Wallace that, "he just might be able to beat me." This alone frightened Roosevelt Democrats because of a star politician was winning everybody over with talks of isolationism and promises of a second roaring twenties (Moe, p. 154-56). The second polling question showed that the public trusted FDR during the war. $61 \%$ of the people asked, favored Roosevelt's decision to assist Great Britain in 1939 and 1940 in the middle of war. This same polling questionnaire also asked, "who do you think would have won the war: Dewey or Roosevelt?" 79\% believed that FDR could win the war, and $84 \%$ said he could at the least make peace negotiations with Nazi Germany (Table 2) [3].

\begin{tabular}{|l|l|l|l|l|}
\hline \multirow{2}{*}{} & \multicolumn{2}{|l|}{1940} & \multicolumn{2}{l|}{1944} \\
\cline { 2 - 5 } & Aid to Britain & & Winning the war & Making peace \\
\hline Favour & 61 & FDR Better & 79 & 84 \\
\hline Opposed & 33 & Dewey Better & 4 & 8 \\
\hline No Opinion & 6 & No Diff/ No Opin & 17 & 7 \\
\hline Total & $100 \%$ & Total & $100 \%$ & 99 \\
\hline$(N)$ & $(257)$ & $(N)$ & $(148)$ & $(148)$ \\
\hline
\end{tabular}

Table 2: Attitudes toward war among potential FDR Defectors.

The public and opponents of more than two presidential terms though had come to the realization that regardless of what is law, when a domestic/global threat is active, the most experienced person should lead in the office of president. Michael Korzi's article states that feeling as such [4]:
Democrats and opponents of the amendment clearly did believe that there might be certain men who would be critical to the leadership of the United States in times of emergency. And, of course, many of them believed that FDR was that man who was needed by his country in an emergency. No less than George Washington had himself made the same claim in his letter to Lafayette about the danger of denying the people experienced leaders in times of emergency [4]. 


\section{Comparisons between Roosevelt and Presidents of the Past}

In terms of presidential power, George Washington had the entire country at his disposal. He could have ruled with an iron fist and establish an American form of monarchy based on what he decided to do once elected as president and who would be his successor. Instead, he set a standard that continues to be felt to this day within the world's most powerful office. Washington decided upon himself to retire after two terms as president, thus establishing a tradition that stood for nearly 140 years. Washington in fact had wanted to only serve one term deeming it as, "too stressful, even for the most able-bodied man." It was only after constant and forced pressure from his cabinet members that he finally caved and ran for reelection for a second term. Richard Moe states:

He was tired, feeling his age, and increasingly disturbed by the growing feud between the two strong-willed principles of his cabinet Thomas Jefferson and Alexander Hamilton, who disagreed on most everything except the need for Washington to serve another term. After hearing from the president on how displeased he was by their feuding, they agreed to quell the controversy, and Washington again responded to what he saw as his duty: he was unanimously elected to a second term (Moe, p. 111).

Roosevelt compares to this immensely because after his eight years were up in 1940, he wanted so dearly to retire to Hyde Park, and leave the public sphere of politics. Much like Washington though, Roosevelt was pressured and begged to return as president to lead them through turmoil and potential global threats. Reluctantly, FDR accepted these pleas based on national duty to safeguarding the peace and keeping foreign threats at a minimum.

Thomas Jefferson on the other hand had no desire or vision for a second term as president, much like Roosevelt's third term. He had been an ambassador to France during Washington's presidency and saw firsthand how poorly a monarchical system of government was. It left such a distaste in his mouth that he said in a letter to a friend stateside from Paris:

"I was much an enemy to monarchy before I came to Europe. I am ten thousand times more so since I have seen what they are. There is scarcely an evil known in these countries which may not be traced to their kind at its source. If some period be not fixed, either by the Constitution or by practice, to the services of the First Magistrate, his office, though nominally elective, will, in fact, be for life; and that will soon degenerate into an inheritance. (Moe, p. 111-112)".

After returning to the states in the final days of Washington's second term, Jefferson backed Washington based on a term limit. Upon his decision to run for the office of president, he declared that if he is elected to a second term, he will follow in Washington's footsteps and serve a term limit of two terms. He had originally only wanted to run for a single term, but after repeated Federalist attacks, and a new rift in the political world of America, Jefferson's desire to uphold his legacy as president forced him to run for reelection (Moe, p. 111). This is almost identical to Roosevelt as one of the biggest factors in his decision was based on his legacy to the New Deal programs. Had they not have been so influential post-depression, he very well might not have run for a third term (Moe, p. 84).

When one is discussing Lincoln, the immediate thought is the American Civil War. When the Civil War ended, he was tasked with rebuilding America from basically the ground up. The era of reconstruction was imminent, and Lincoln needed the nation behind him to get her back onto her feet. Many agree that the programs he had laid out were of solid ground and would have reintegrated the South much quicker into industry. Lincoln's "Ten Percent Plan" or Proclamation of Amnesty and Reconstruction allowed for those who were aggressors of the Union were to not be met with harsh conditions upon reentry into the Union (k12.ny, p. 1). This gave a full pardon for and restoration of property to mostly all Confederates engaged in the Civil War rebellion. The uplifting gesture of Lincoln to forgive and forget, parallels Roosevelt and how he approached Republicans and Democrats involved with Hoover and the onset of the Great Depression. Roosevelt's programs involved massive government restructuring of the public domain, thus garnering tons of public trust and support for these programs. Lincoln wanted to make sure that reconstruction era Americans would not be reprimanded after such a tumultuous time. Roosevelt in turn wanted to make sure that his New Deal programs would foster a sense of bringing the nation together after such harsh times. Because of this, the New Deal is often considered the second reconstruction period because of how much the Great Depression damaged the lives of Americans just like the Civil War had done 80 years prior.

\section{The Decision to Run for Reelection}

During the lead up to the 1940 election every single journalist, politician, friend, and foe of Roosevelt had no idea what his intentions were. Was he going to retire to Hyde Park which he so wished to do so in 1938? Was he going to hand pick his successor in the Democratic party since they had such a hard time gathering support behind a single candidate? Or was he going to break the long-standing tradition of two terms, and try his hand at a third term presidency? In Richard Moe's book, he explains that Roosevelt had no confidence in any of the potential successors his party had brought forth (p. 83-88). Jim Farley was an ambitious man with no guide. Henry Wallace couldn't handle the spotlight as president. John Garner had become distanced from FDR's New Deal programs, and he feared that Garner would try and restructure many of them. With hardly no options on the table, this factored into why Roosevelt saw himself as the perfect liberal and democrat of the time.

Another qualification that FDR had was his military history in a potential World War II. Having been the Assistant Secretary of the Navy during World War I, he helped oversee naval operations which gave him great admiration amongst military personnel in both government and the public eye. Roosevelt's opponents were inexperienced in the field of military knowledge but attacked Roosevelt for having internal administration issues during the 1940 and 1943 primary seasons. Michael Korzi writes that Roosevelt directly responded as quote:

Roosevelt himself responded directly to the idea that his administration was "tired" or "quarrelsome" with his assertion, in accepting the Democratic nomination, that his administration represented "experience" while that of his opponents would represent "immaturity," Others, at the Democratic convention, would also make the same contrast between "age and experience" and "youth and inexperience" [4].

FDR's goal was to ensure that there would be an extremely limited breach of global democracy, and that a system of nation(s) would have to defend these values. His opponents on the Republican side had screamed for isolationism and called it "Europe's problem. Not ours." If 
one allows for a systematic destruction of democracy and peace inside of Europe, then there will be a constant threat on our own American values. Had Roosevelt been unable to serve beyond the office of Assistant Secretary of the Navy, and the appointment of Stimson into his war cabinet, the nation would have been deprived of his wartime leadership, widely regarded as successful [4].

The outside world also kept a very close watch on what was going on in America during the election cycle. Winston Churchill for example butted heads with Roosevelt on many occasions but had the utmost respect for him. Churchill went as far as to say that had FDR not been reelected in 1940, the world would have been a very different place. This shows that not only did Churchill want FDR to be reelected but could not see anyone else taking his spot and commanding his government like Roosevelt could. During lead up to 1940, Churchill was amid a courtship towards Roosevelt. In this drawn out plea for help, it was asked that the Americans supply the UK with arms to defend themselves with. Roosevelt knew that if these weapons had gotten into the Axis hands, that impeachment was likely, and the collapse of Allied Europe was bound to happen (Moe, p. 138). Also, hardly anybody knew who FDR's opponents were during the election. Since they all had little to no foreign policymaking in their repertoire, it would only show clear support in favor of Roosevelt for diplomatic topics.

FDR also knew that if Europe was to not go to full scale armed conflict, he had to shift focus on the campaign trail back to domestic strengthening through more government programs. The public still needed jobs and the nation was still going through a depression. Roosevelt selected Henry Wallace as his running mate, who before this appointment was the head of Agriculture. Through Wallace's programs, the blue-collar worker made up the backbone of FDR's 1940 bid. Adam Cohen [2] writes that the Agricultural Adjustment Act was just the beginning of the New Deal programs, and one that launched Wallace into the public light:

The AAA radically changed the economics of American farming, and it also marked an early milestone for the New Deal. It was the Roosevelt administration's first law that committed the government to caring for its destitute citizens. It was "the farmers with their solidarity, their faith in mass action, their courage in the face of violence and arrest, who have supplied us with one of the few hopeful signs in the depression" [2].

\section{Counter Argument on Presidential Ambition}

In Bryant Smith's journal The Third Term and the Dead Hand, he goes on to say that when a leader is clouded by ambition and greed, he cannot achieve that goal by a means that is seen as moral $[5,6]$. In the realm of Roosevelt, many on both sides of the isle saw his reelection bid as one of ambition and greed, much like Jackson, instead of service to his country in a time of turmoil. Jim Farley was one such opponent of FDR within the Democratic party due to the fact that he believed Roosevelt to dismiss anyone who was not on the same ideological, social, or political level (Moe, p. 86-87). Farley and Garner saw Roosevelt as a man who could do no wrong in his own eyes, and that what he envisioned for America was far superior than any of his colleagues. Also, when Cordell Hull rejected FDR's invite as Vice President, Roosevelt felt a sense of anger as he had almost always gotten his way in terms of politics.

\section{Conclusion}

Roosevelt felt that his third term decision was duty and service based, rather than greed or ambition. He did not want to go back to the office of president after his second term was up. He romanticized about retiring to Hyde Park and living out his live relatively stress free. Much like how Washington has not been a fan of even a second term, let alone a third term. Roosevelt had no intentions of reelection, but with the war looming in Europe at the expense of our allies, and his beloved government programs at risk, he could not sit back and allow for that to take place. This became his call to duty for the American people and their interests in the world in which they lived. Much like Lincoln's quote, "you cannot change horses midstream," Roosevelt saw himself as the most qualified candidate going forward. His ability to command his government, influence the people around him, and to push a progressive and publicly appealing agenda in a time of despair was his strongest attributes. He did not see himself as a man who wanted more out of his presidency as Richard Moe states in his book Roosevelt's Second Act, but as a man who wanted to hold himself, and the nation, to standard which it had become on the global scene.

\section{References}

1. Richard M (2013) Roosevelt's Second Act: The Election of 1940 and the Politics of War. Oxford University Press.

2. Cohen A (2010) Nothing to Fear: FDR's Inner Circle and the Hundred Days That Created Modern America. Penguin Books.

3. Norpoth H (2012) To Change or Not to Change Horses: The World War II Elections. Presidential Studies Quarterly 42: 324-342.

4. Michael KJ (2008) Theorizing Presidential Tenure: The Difficult Case of FDR's Fourth Term. Congress \& the Presidency 35: 39-64.

5. Bryant S (1949) The Third Term and the Dead Hand. Southwestern Social Science Quarterly 29: 273-279.

6. Linda A (2018) Abraham Lincoln. The Ten Percent Plan. 